\title{
On Dokuzuncu Yüzyılda Çanakkale Boğazı'nda Yeni Bir Savunma Noktası: Bigalı Kalesi
}

\section{Fort Bigali: A Nineteenth-Century Defensive Position in the Dardanelles}

\author{
Özkan Keskin ${ }^{1}$ []
}

'Doç. Dr., Çanakkale Onsekiz Mart Üniversitesi, Fen-Edebiyat Fakültesi Tarih Bölümü Çanakkale, Türkiye

ORCID: Ö.K. 0000-0003-0401-7988

\author{
Sorumlu yazar/Corresponding author: \\ Özkan Keskin, \\ Canakkale Onsekiz Mart Üniversitesi, \\ Fen-Edebiyat Fakültesi Tarih Bölümü \\ Çanakkale, Türkiye \\ E-posta/E-mail: ozkankeskinn@yahoo.com
}

Başvuru/Submitted: 02.04 .2021

Revizyon Talebi/Revision Requested:

23.04.2021

Son Revizyon/Last Revision Received:

08.05.2021

Kabul/Accepted: 14.05 .2021

Online yayın / Published online: 05.07.2021

Atıf/Citation: Keskin, Özkan. "On dokuzuncu Yüzyılda Çanakkale Boğazı́nda Yeni Bir Savunma Noktası: Bigalı Kalesi" Osman/ı Bilimi Araştırmaları 22, 2 (2021): 255-275.

https://doi.org/10.26650/oba.908725

\section{öz}

On dokuzuncu yüzyıl başında Osmanlı-Rus gerginliğinin giderek tırmanmasıyla Çanakkale Boğazı́nda tabya ve batarya yapımını devletin öncelikli işleri arasına girmişti. Osmanlı Devleti, Rusya ile yapmış olduğu 1799 ittifakına rağmen barışın kalıcı olmayacağını görüyor ve Fransa'ya yakınlaşmayı tercih ediyordu. Gelişmeler Osmanlı yönetiminin öngörülerinde yanılmadığını gösterdi ve Rusya ile gerginleşen ilişkiler 1806 'da savaşa dönüştü. Bu noktada İngiltere, müttefiki Rusya'nın tüm askeri kuvvetlerini Avrupa'da devam eden IV. Koalisyon Savaşında kullanmasını istiyordu. Osmanlı Devleti'nin sulh müzakerelerine oturtulması, ancak İstanbul'un zorlanması ile mümkün olabilirdi. Bu amaçla Çanakkale Boğazı açıklarında bekleyen İngiliz donanması 19 Şubat 1807'de Boğaz'dan kolayca geçerek ertesi gün İstanbul Boğazı́na demirledi. İstanbul'daki İngiliz baskısı devam ederken, Çanakkale Boğazı́nın Avrupa yakasında Bigalı adıyla bir tabya yapımına başlandı. Ancak Sultan III. Selim'in de tespit ettiği gibi, Çanakkale Boğazı'ndaki görevliler tabyanın yapımına gereken önemi vermemişlerdi. Bu çalışmada başta Osmanlı arşiv belgelerinden yararlanılarak, mimarı ve yapım tarihi literatürde tam olarak bilinmeyen Bigalı Kalesi'nin yapımı ele alınacaktır. Anahtar sözcükler: Çanakkale Boğazı, Bigalı Kalesi, tabya, Osmanlı İmparatorluğu

\section{ABSTRACT}

In the early nineteenth century, the escalation of Ottoman-Russian tensions forced the Ottoman empire to construct forts and batteries along the Dardanelles Strait. Despite the 1799 alliance with Russia, the Ottoman Empire sought diplomatic proximity with France. At the time, Great Britain wanted Russia as an ally and aimed to use its military forces at the Fourth Coalition War that occurred in Europe against France. To include the Ottoman State into peace negotiations, the British Fleet crossed the Strait on February 19, 1807 and anchored at the Bosphorus on the next day. Despite the continued 
pressure exerted by the British on Istanbul, the construction of a fort named Bigali on the European side of the Dardanelles had begun. Thus, the study examines the construction of Fort Bigali, unveils its little-known architect and construction date, by referring primarily to Ottoman archival documents.

Keywords: Dardanelles, Fort Bigalı, bastions, Ottoman Empire 


\section{Giriş}

Kavşaklar, geçitler, darboğazlar, denize uzanan burun ve adacık gibi stratejik bir yeri, bir geçidi korumak veya düşman tehlikesi belirdiğinde şehirde yaşayanların sığınabileceği muhtelif büyüklük ve şekillerde, etrafı kalın duvarlarla çevrili, içerisinde yaşam alanlarının da bulunduğu askerî yapılar kale olarak adlandırılmıştır. Ancak formları ve işlevleri açısından farklılık gösteren hisar, sur, tabya, palanka gibi birçok yapının kale tanımlaması altında toplandığı ve -Bigalı Kalesi/Tabyası örneğinde olduğu gibi- aynı yapının farklı şekillerde isimlendirilmesinin karışıklıklara neden olduğu görülmektedir. ${ }^{1}$ Bir kalede genel olarak sur, tabya, hendek, iç kale, kule, şaranpo ve metris gibi savunma özelliğini artıran yapıların yanında, kalenin bir yaşam alanı olması münasebetiyle içinde kışlak, hamam, cami, su deposu, varoş ve ambar gibi bölümler de bulunmaktadır.

Osmanlı coğrafyasında kaleler hemen tüm imparatorluğa yayılmakla birlikte, Habsburg ile olan uzun ve çetin mücadele, bu cihette yoğun askerî yapılaşma olarak kendini göstermiştir. Karlofça sonrası Habsburg serhaddinde daha önce benzeri görülmeyen nispette kale ve palanka yapımına başlanması, Osmanlı yönetiminin geliştirdiği savunma refleksi olarak yorumlanmaktadır. ${ }^{2}$ Bir diğer baskı noktası on yedinci yüzyıl sonundan itibaren Kırım bölgesidir ve Rusya'nın artan tazyiki, Kırım'da kale yapımının devletin öncelikleri arasına dahil edilmesine neden olmuştur. Nitekim Azak'ın Rusların eline geçmesi ve Karadeniz'in, hatta payitahtın güvenliğinin tehlikeye düşmesi üzerine Bâbıâli yönetimi Kerç Boğazı'nın iki yakasına yeni kaleler inşa ederek muhatabına karşılık vermiştir. ${ }^{3}$ Rusya'nın saldırgan siyaseti on sekizinci yüzyılın ikinci yarısında daha da artmış ve Kırım'ın 1783'te ilhakından sonra, Osmanlı Devleti'nin bölgede yeni kaleler inşa etmesi kaçınılmaz hale gelmiştir. $\mathrm{Bu}$ doğrultuda eski Ceneviz kalesi kalıntıları üzerinde Anapa Kalesi inşa edilerek Kuzey Kafkasya'da önemli bir mevzi oluşturulmuştur. ${ }^{4}$

\section{Çanakkale Boğazı'nın Tahkimi}

Habsburg ve Rus sınırı dışında, Osmanlı coğrafyasında kale, tabya ve benzeri savunma yapılarının inşa edildiği en önemli noktalardan biri de Çanakkale Boğazıydı. Henüz İstanbul'un fethi hazırlıkları kapsamında 1452'de Rumeli Hisarı yapılarak İstanbul Boğazı geçişi kontrol altına alınmış ve Osmanlı-Venedik yönetimleri arasında karşılıklı antlaşma yapılmıştı. Ancak

1 Söz konusu askerî yapılardan hisar, sur, palanka, tabya, metris, şaranpo ve şanes/şanis hakkında ayrıntılı bilgi için bkz. Semavi Eyice, "Kale," Diyanet Vakfi İslam Ansiklopedisi, c. 24 (İstanbul: Diyanet Vakfi 2001), 234; Mahir Aydın, "Kaleler" Osmanlı Askeri Tarihi, editör Gültekin Yıldız (İstanbul: Timaş, 2017) içinde, 2234; Ömer Gezer, Kale ve Nefer Habsburg Serhaddinde Osmanlı Askeri Gücü (1699-1715) (İstanbul: Kitap Yayınevi, 2020), 122-125.

2 Gezer, Kale ve Nefer, 67.

3 Gezer, Kale ve Nefer, 72.

4 Cengiz Fedakâr, Kafkasya'da Imparatorluklar Savaşı Kırım'a Giden Yolda Anapa Kalesi (1781-1801) (İstanbul: İş Bankası, 2014), 50-54. 
Osmanlıların Balkan topraklarında izlediği genişleme siyaseti, bu antlaşmanın uzun ömürlü olmasına engel oldu. Bosna'nın fethinin ardından papalığın önderliğinde ve Macarların da katılımıyla oluşan müttefik güç Osmanlılara 1463'te savaş ilan etti. Venedik donanmasının Çanakkale önlerine gelerek Boğaz’ı kapatması üzerine, Osmanlı yönetimi 1463-1464 kışında Kilitbahir ve Sultaniye hisarlarını yaparak, Venedik donanmasının İstanbul'u ve deniz üssü olan Gelibolu’yu tehdit etmesinin önüne geçmiş oldu. ${ }^{5}$

Çanakkale Boğazı'nda ikinci büyük tahkimat, Malta korsanlarının üs olarak kullandığı Girit'i ele geçirmek için düzenlenen seferler sırasında yapıldı. 1645'te başlayan ve yirmi dört yıl süren Girit Seferi sırasında, Venedik donanması, ikmali engellemek için birçok defa Çanakkale Boğazı'nı abluka altına aldı. Venedik tehlikesi Çanakkale Boğazı'ndaki istihkâmların artırılması zaruretini açıkça ortaya koyduğundan, Sadrazam Köprülü Mehmed Paşa'nın (1578-1661) ricası üzerine, Sultan IV. Mehmed'in (salt. 1648-1687) annesi Hadice Turhan Sultan (ö. 1683) tarafından 1661'de Boğaz'ın girişinde Kumkale ve Seddülbahir kaleleri yaptırılarak güvenlik artırıldı. ${ }^{6}$

1768'de başlayan Osmanl1-Rus Harbi sırasında, Amiral Aleksey Grigoryeviç Orlov (17371808) komutasında Baltık'tan yola çıkan Rus donanmasının Batı Anadolu kıyılarına kadar gelerek 1770’te Çeşme'de Osmanlı donanmasını bozguna uğratması ve Çanakkale Boğazı önlerine gelmesi, tahkimatın teftişini gündeme getirdi. Aslen bir Macar asilzâdesinin oğlu olan ve Fransa ordusunda görev yapan Baron François de Tott (1733-1793) bizzat Sultan III. Mustafa (salt. 1757-1774) tarafından Çanakkale Boğazı'nı tahkim etmekle görevlendirildi. Rus donanmasının Boğaz önünde bulunmasının yarattığı paniğin de etkisiyle acilen bölgeye gönderilen Tott, öncelikle girişte yer alan Seddülbahir ve Kumkale'yi inceledi ve bu iki istihkâmın hem donanım hem de askerlerin savaş kabiliyeti bakımından yetersiz olduğunu ve yeni savunma noktalarının inşa edilmesi gerektiğini belirtti. ${ }^{7}$ Türk kaptanlarından akıntıların yönü ve şiddeti hakkında bilgi alarak, her iki yakada yapılacak yeni istihkâmlar için savunmaya en elverişli yerleri belirledi. Tott'un çalışmaları neticesinde Çanakkale Boğazı'nda bazı yapılar elden geçirilirken, yeni istihkamlar da inşa edildi. ${ }^{8}$

\section{İngiliz Donanması'nın Boğaz'dan Geçişi ve Bigalı Tabyası'nın Yapımı}

İhtilal sonrası neredeyse tüm Avrupa devletlerini karşısına alan Fransa, İngiltere'nin başını çektiği ülkelerle Koalisyon Savaşları olarak adlandırılan mücadeleye girişmişti. Bu mücadele,

5 Halil İnalcık, Devlet-i 'Aliyye, c.1 (İstanbul: İş Bankası, 2012), 113,114; Feridun M. Emecen, Osmanlı İmparatorluğu'nun Kuruluş ve Yükseliş Tarihi (1300-1600) (İstanbul: İş Bankası, 2015), 148-149.

6 İsmail Hakkı Uzunçarşıll, Osmanlı Tarihi, III-1 (Ankara: Türk Tarih Kurumu, 1995), 400; Lucienne ThysŞenocak, Osmanlı İmparatorluğu'nda Kadın Baniler Hadice Turhan Sultan (İstanbul: Kitap, 2009), 131-138.

7 Baron de Tott, Türkler ve Tatarlara Dair Hattralar (İstanbul: Tercüman 1001 Eser, ty), 251, 254.

8 Baron de Tott, Türkler, 259, 267. Örneğin Tott, Değirmenburnu Tabyası'nın yapılanlar içinde en iyilerinden biri olduğunu belirtir. 
Fransa'nın yayılmacı planlarının bir sonucuydu ve Avrupa' daki dengeleri temelinden sarsacak nitelikteydi. Söz konusu siyaset çerçevesinde Napolyon'un Temmuz 1798'de Mısır'ı işgal etmesi, Osmanlı Devleti'nin de Avrupa'daki mücadeleye dahil olmasına neden oldu. Fransız işgaline karşı Rusya ve İngiltere ile 1798-1799'da ittifak yapan Osmanlılar, bilhassa Balkan toprakları üzerindeki planları nedeniyle Rusya'ya güvenilemeyeceğinin farkındaydı. Ayrıca Mısır'ın tahliyesi sırasında İngiltere'nin ayak sürüyen tutumu da unutulmuş değildi. Yine de iki müttefik güç, Fransa'ya karşı yürütülmekte olan mücadeleye katılması konusunda Osmanlı Devleti'ne baskıda bulunuyordu. Ancak Fransa'nın müttefiklere karşı 1805 'te Ulm ve Austerlitz'de, 1806'da Jena'da kazandığı zafer karşısında, Bâbıâli yönetimi İngiltereRusya bloğuna nazaran Fransa'ya yakınlaşmayı daha isabetli bir tercih olarak değerlendirdi. ${ }^{9}$ Gelişmeler Osmanlı yönetiminin öngörülerinin yerinde olduğunu göstermiş ve Rusya ile gerginleşen ilişkiler Aralık 1806'da savaşa dönüşmüştü. Bu noktada İngiltere, Osmanl1Rus Harbi'nin bir an önce sona ermesini istiyor ve müttefiki Rusya'nın tüm kuvvetlerini Avrupa'da devam eden IV. Koalisyon Savaşında kullanmasını gerekli görüyordu. Osmanlı Devleti'ni -Rusya'nın talepleri de dikkate alınarak- sulh müzakerelerine zorlamayı öngören planın gerçekleşmesi, ancak İstanbul'a yönelik bir deniz harekâtı ile mümkün olabilirdi. Hatta İngiltere Elçisi Charles Arbuthnot (1767-1850), Osmanlı Devleti’ni tekrar kendi taraflarına çekmek için küçük bir donanmanın bölgede görünmesinin, tüm diplomatik taktiklerden daha etkili olabileceğini ifade ediyordu. ${ }^{10} \mathrm{Bu}$ amaçla Amiral Thomas Louis kumandasındaki 5 harp gemisinden oluşan İngiliz filosu, 21 Aralık 1806'da Bozcaada’ya gelmiş ve bu gemilerden ikisi 27 Aralık 1806' da İstanbul'a doğru yola çıkmıştı. ${ }^{11}$

Arbuthnot ile yapılan müzakerelerden bir sonuç çıkmadığı gibi elçinin tavrının tehdit boyutuna ulaştığı görülüyordu. 23 Aralık 1806'da Bâbıâli'nin Rusya'ya savaş ilanı ve Rus Elçisi Andrey İtalinski'nin (1743-1827) (ilk elçiliği 1802-1806) İstanbul'u terk etmesinden sonra Osmanlı ve İngiliz yetkilileri arasındaki diplomatik görüşmeler, artık karşı tarafı oyalama ve vakit kazanma amacına yönelik olarak yapılıyordu. Tehlikenin farkında olan Sultan III. Selim (salt. 1789-1807) savaş ilanının hemen arifesinde Fransa'nın İstanbul'daki elçisi Sébastiani (Horace François Bastien Sébastiani de La Porta, 1771-1851) aracılığıyla Napolyon Bonapart'tan (imp. 1804-1814) topçu, piyade ve denizci subaylar, mühendisler ve hatta generaller dahi talep etmişti. ${ }^{12}$ Bu arada aslen Fransız olan ve 1805 'ten itibaren Osmanlı ordusuna danışmanlık yapan Antoine Juchereau de Saint-Denys (1778-1842) Çanakkale’ye

9 Fatih Yeşil, Trajik Zafer Büyük Güçlerin Doğu Akdeniz'deki Siyasi ve Askeri Mücadelesi (1806-1807) (İstanbul: İs Bankası, 2017), 35-42.

10 Aysel Y1ldız, "Vaka-y1 Selimiyye or the Selimiyye Incident: A Study of the May 1807 Rebellion" (Doktora tezi, Sabanc1 Üniversitesi, 2008), 270.

11 Ahmed Cevdet, Tarih-i Cevdet, c. 8 (Dersaadet, 1309), 108; Fatih Yeşil, "İstanbul Önlerinde Bir İngiliz Filosu: Uluslararası Bir Krizin Siyasi ve Askeri Anatomisi," Nizâm-ı Kadîm'den Nizâm-ı Cedîd'e III. Selim ve Dönemi, editör Seyfi Kenan (İstanbul: İSAM, 2010) içinde, 409.

12 Vernon J. Puryear, Napoleon and the Dardanelles (Berkeley and Los Angeles: University of California Press, 1951), 120. 
gönderilerek Boğaz'ın savunma durumu hakkında rapor hazırlaması istendi. Saint-Denys, usta bir subayın komuta ettiği bir filonun, uygun rüzgârın da yardımıyla Boğaz’ı rahatlıkla geçebileceğini ifade ederek, yeni bataryalarla Nara Burnu, Kilitbahir ve Kala-1 Sultaniye kalelerinin desteklenmesini önerdi. ${ }^{13}$ Denys'in tekliflerini dikkate alan Bâbıâli, mühimmat nakli, tabya yapımı gibi çalışmalara hız verirken, Çanakkale Boğazı'nın tahkimini, Boğaz Nazırı unvanıyla sabık İrâd-ı Cedîd Defterdarı Feyzullah Efendi’ye verdi. Biga Mütesellimi Hadımzâde Osman ise İngilizlerin karaya asker çıkarması ihtimaline karşı sahilleri korumakla görevlendirildi. Ayrıca yine Saint-Denys'in Boğaz'ın harp gemileri ile kapatılması yönündeki tavsiyeleri üzerine hazırlanan donanma, Kaptanıderya Salih Paşa komutasında Ocak 1807'de Çanakkale'ye gönderildi. ${ }^{14}$

Hazırlıklar devam ederken, gerek Çanakkale açıklarında bulunan İngiliz filosu yetkilileri ve gerek Büyükelçi Arbuthnot ile yapılan uzun müzakerelerden bir sonuç alınamıyordu. Bu durumda Arbuthnot, Kasım 1806'dan beri İstanbul'da demirli bulunan Endymion'da 29 Ocak 1807 gecesi elçilik personeline ve İngiliz tüccarlara verdiği akşam yemeği sonrası Osmanlı makamlarından izin almadan başkenti terk ederek 31 Ocak’ta Çanakkale Boğazı girişindeki İngiliz filosuna katıldı. ${ }^{15}$ Müzakereler Boğaz'da yapımı devam eden tabyalar için zaman kazandırıyordu. Ancak İngiliz donanması da artık geçiş için uygun hava şartlarının oluşmasını beklemekteydi ve Arbuthnot ile Amiral John Thomas Duckworth (1748-1817), müzakerelerden sonuç alınamaması halinde güç kullanabileceklerine dair yetkilendirilmişlerdi. ${ }^{16}$ Nihayet 18 Şubat $1807^{\prime}$ de rüzgârın güney-güneybatıdan esmeye başlaması ve ertesi gün şiddetini artırması üzerine, Amiral Duckworth komutasındaki 11 harp gemisinden oluşan İngiliz filosu 19 Şubat 1807 sabahı demir alarak Çanakkale Boğazı'na giriş yaptı. Boğaz'daki dört büyük kaleden ve tabyalardan yapılan atışlardan fazla etkilenmeyen filo, Nara Burnu'nda karaya asker çıkararak burada bulunan topları çiviledi. Dört saat süren çatışmanın ardından, İngiliz filosu ertesi gün İstanbul Boğazı açıklarına demirlemişti. ${ }^{17}$

Kurban Bayramı dolayısıyla Boğaz'da demirli Osmanlı gemilerinde ve sahildeki birliklerde az sayıda asker bulunmas $1^{18}$ geçişin kolaylığını kısmen açıklamaktadır. ${ }^{19}$ Fakat

13 Juchereau de Saint-Denys, Révolutions de Constantinople en 1807 et 1808, Tome Second (Paris: Libraire de Brissot-Thivars, 1819), 53-55; Johann Wilhelm Zinkeisen, Osmanlı Imparatorluğu Tarihi, c.7, çev. Nilüfer Epçeli, çev. kontrol Kemal Beydilli, editör Erhan Afyoncu (İstanbul: Yeditepe, 2019), 305.

14 Yeşil, "İstanbul Önlerinde," 416, 418 n.91, 430.

15 Ahmed Cevdet, Tarih-i Cevdet, c.8, 109; Zinkeisen, Osmanll, c.7, 303; Y1ldız, "Vaka-yı Selimiyye," 272, 273; Yeşil, "İstanbul Önlerinde," 432-434.

16 Yıldız, "Vaka-yı Selimiyye," 277. Hatta Osmanlılar müzakere teklif ederlerse Türklere yarım saatten fazla süre verilmemesi Duckworth'a verilen emirler arasındaydı. Puryear, Napoleon and the Dardanelles, 128.

17 Mütercim Ahmed Âsım Efendi, Assm Efendi Tarihi, c.1, haz. Ziya Y1lmazer (İstanbul: Türkiye Yazma Eserler Kurumu Başkanlı̆̆ı, 2015), 480-482; Yeşil, “İstanbul Önlerinde,” 432-434, 447-449.

18 Câbî Ömer Efendi, Câbî Tarihi, c.1, hazırlayan Mehmet Ali Beyhan (Ankara: Türk Tarih Kurumu, 2003), 101, 102 .

19 İngiliz donanması geçiş sırasında 13 askerini kaybetmiş, 66'sı da yaralanmıştı. İngiliz donanmasının İstanbul' da kaldığı 10 gün boyunca Çanakkale Boğazı'ndaki hazırlıklar devam etmiş ve Duckworth dönüşte 49 askerini 
İngiliz filosunun geçişe başladığı esnada sahilden yapılan isabetsiz ve zayıf atışlar tabyaların hazır olmadığını göstermektedir. Kaldı ki Boğaz tahkimatı eski zaman donanmalarının geçişine engel olabilecek şekilde yapılmıştı ve yeni tarz harp gemilerine karşı kale ve tabyaların da modern askerî mühendislik bilgisi dahilinde inşa edilmeleri gerekiyordu. Ayrıca düşman donanmalarının Boğaz' dan geçişine dair daha önce bir tecrübenin yaşanmaması, görevlilerde rehavete neden olmuş ve tahkimat konusuna gereken önem verilmemişti. ${ }^{20}$ Halbuki İngiliz filosunun geçişinden iki hafta önce Kaptanıderya Salih Paşa'nın Kumkale'deki top ve tabyaları teftişinde, mermer gülle atan toplarla 10 kıyye barut konularak yapılan atışlarda, mermer güllelerin parçalandığı, barutun 6 kıyyeye düşürülmesi durumunda güllelerin dağılmadığını saraya bildiren kaimesi ${ }^{21}$ topçu neferâtının teknik bilgilerinin ve talimlerinin yetersiz olduğu izlenimini vermektedir. Ayrıca İngiliz filosunun geçişinden neredeyse bir ay önce, Rusya sefiri İtalinski'yi Malta’ya götüren Albay Harvey komutasındaki Standard korvetinin, açılan ateşe rağmen büyük hasar almadan Boğaz'dan geçişi istihkamların yetersizliğine dair önemli bir göstergedir. ${ }^{22}$ Geçişin gerçekleştiği gün Fransa'nın Çanakkale Konsolosu'nun, elçisine gönderdiği mektupta çatışmadan bahsettikten sonra "Rumeli sahilinde asla tabya olmadi $\breve{g l}$ " yönündeki ifadesi, bu cihette Duckworth'a sorun çıkaracak bir tabyanın bulunmadığını teyit etmektedir.

İngiliz filosunun İstanbul'da kaldığı on gün boyunca ve Çanakkale Boğazı'ndan çıkış yaptıktan sonra da Çanakkale'de tabya inşaatına devam edilmiştir. Bu arada İngiliz filosunun rahat geçişinden sorumlu tutulan Boğaz Nazırı Feyzullah Efendi idam edilir. Yerine eski Tersâne-i Âmire Defterdarı Aziz Efendi atanır. ${ }^{24} 4$ Mart 1807'de Çanakkale'ye ulaşan Aziz Efendi, Nara Burnu tabyasının bitmek üzere olduğunu, karşısında bulunan ve sonradan Bigalı olarak adlandırılacak 25 topçeker Güllük tabyasının inşaatına başlandığını bildirmektedir. ${ }^{25}$ Yeniden inşa olunan veya tahkim edilen tabyaların teknik çizimleri, Elçi Sébastiani'nin şahsında doruğa ulaşan nüfuza paralel olarak Fransız mühendisler tarafından yapılıyordu. ${ }^{26}$ Hatta İngilizlerle müzakereler henüz devam ederken Sébastiani’nin harp yaveri Baron de Lascours (1786-1850) önce Erzurum'a, ardından da artan gerginlik nedeniyle tahkimat yapımına katkıda bulunması amacıyla Çanakkale Boğazı'na gönderilmişti. ${ }^{27}$

21 T.C. Cumhurbaşkanlığı Devlet Arşivleri Başkanlığı Osmanlı Arşivi (BOA), Hatt-1 Humâyûn (HAT.) 40/2007, 26 Zilkade 1221 (4 Şubat 1807).

22 Yeşil, Trajik Zafer, 56.

23 BOA, HAT. 159/6636, 29 Zilhicce 1221 (9 Mart 1807).

24 III. Selim, İngiliz filosunun geçişinde Feyzullah Efendiyi asıl sorumlu olarak görür ve katledilmesini emreder. Hatta “... on güne dek başını Bâb-ı Humâyûna vaz' eyle yohsa pek infi 'al ederim” ş̧eklinde Kilitbahir Muhafizı Ali Paşa'yı da uyarır. BOA, HAT. 268-15663; Mütercim Âsım, Âsım Efendi Tarihi, c.1, 490. Feyzullah Efendi'nin muhallefâtı, sarraf ve esnafa olan borçlarının ödenmesi şartıyla münasip bedel ile alınıp İrâd-1 Cedid'e kaydedilir. BOA, HAT. 107/4206, 29 Z 1221 (9 Mart 1807). 
İngiliz filosunun İstanbul önlerine geldiği gün, Fransız General Auguste Marmont'un (1774-1852) gönderdiği beş mühendis de başkente ulaşmıştı. Bu mühendislerden biri olduğu anlaşılan $^{28}$ ve Dalmaçya ordusundan gelen Fransız subay Coutaillout, ${ }^{29}$ yapımına -Aziz Efendi'nin yukarıda bahsi geçen ifadesinden anlaşılacağı üzere- Mart ayı başında başlanan Bigalı Tabyası'nın teknik sorumluluğunu üstlenmiştir. Nitekim, Coutaillout'nun - Osmanlı belgesindeki yazımı ile Katalyo, Gatalyo - İstanbul'daki elçisine gönderdiği raporda, planını çizdiği tabyalar arasında Boğalıyı [Bigalıyı] sayması, tabyanın mimarının kim olduğu sorusuna da netlik kazandırmaktadır. Coutaillout, bahsi geçen raporda, 32 topa sahip olacak şekilde Nara Burnu'nda yapılan tabya ateşiyle karşılıklı inşa edilen Bigalı Tabyası'nda 28 top bulunduğunu ifade etmektedir. ${ }^{30}$ Coutaillout'ya bu hizmeti karşılı̆̆ında Nisan 1807'den itibaren tercüman ücreti dahil aylık 500 kuruş ödenecekti. ${ }^{31}$ Ancak Bigalı'nın da aralarında bulunduğu yapımı devam eden bazı tabyaların, aslında gereken vasıfları taşımadıkları ve acil ihtiyaca binaen vücuda getirildiği anlaşılmaktadır. Nitekim, Kilitbahir Muhafızı Ali Paşa'nın, kale bitişiğinde inşa ettirdiği tabyaların iki buçuk günde tamamlandığını ifade etmesine karşılık, Sultan III. Selim'in “.... Ali Paşanın iki günde yaptığı tabyalar işe yaramaz vakit kazanıldıkça bir tarafdan elden geçmelidir..." "32 şeklindeki hatt-1 humâyûnu, bu kadar kısa sürede yapılan tabyaların gereken vasıfları taşımasının mümkün olamayacağının, bizzat sultan tarafından tespit ve kabulü anlamına gelmesi bakımından önem arz eder.

\section{Tabyadan Kaleye: Bigalı Kalesi}

Şubat 1807 tecrübesi, Boğaz’ın geçilemeyeceğine olan inancın yok olmasına ve Çanakkale Boğazı'nın tahkimâtı konusunda devletin teyakkuzda bulunmasına neden olmuştur. Bu bağlamda Şubat 1815 'te Nara Burnu ve karşısında bulunan Bigalı'da birer mükemmel tabya yapımına karar verilmiştir. Mimar Halifesi Seyyid Mehmed Ağa marifetiyle yapılan keşif sonucunda, Bigalı Tabyası için 113.500 kuruşluk, Nara Burnu'nda yapılacak tabya için ise 253.677 kuruşluk bir bütçe çıkarılır. Toplamda ihtiyaç duyulan 367.177 kuruşun 100.000 kuruşu müteveffa Hanyalı Hüseyin'in ve müteveffa Hacı Mustafa Paşa'nın muhallefâtından aktarılmasına ve kış mevsiminin geçmesinden sonra inşaata başlanmasına karar verilir. ${ }^{33}$

Köprülüzâde M. Fuad, çeviriyazı Selma Günaydın (Ankara: Türk Tarih Kurumu, 2013), 75.

28 Puryear, Napoleon and the Dardanelles, 132. Söz konusu beş mühendisin gecikmesi Sébastiani'de endişeye neden olmuştur. Puryear, Napoleon and the Dardanelles, 135.

29 Édouard Driault, Napoléon'un Şark Siyâseti, 86.

30 BOA, HAT. 175/7614, 7 Muharrem 1222 (17 Mart 1807). Puryear, 17 Şubat tarihini takip eden on gün içinde Çanakkale Boğazı'na 306 top ve 16 havan yerleştirildiğini ifade eder: Puryear, Napoleon and the Dardanelles, 143. Feyzullah Efendi'nin azlinden sonra yerine atanan Aziz Efendi ile memuren bölgeye gelen Yeniçeri Kâtibi Rüşdü Efendi tabyada inşaat işlerinden sorumluydu. Mütercim Âsım, Âsım Efendi Tarihi, c.1, 490.

31 BOA, Cevdet Hariciye (C. HR.) 124/6183, 2 Muharrem 1222 (12 Mart 1807). Bu ödeme emrine göre Le Clerc (Leclerc) ve Fileurages da Çanakkale Boğazı'nda mühendis olarak göreve başlamışlardı ve sırasıyla 500 ve 300 kuruş aylık tahsis edilmişti.

32 BOA, HAT. 36/1847, 6 Muharrem 1222 (16 Mart 1807).

33 BOA, Cevdet Askeriye (C. AS.) 783/33154 Lef 3, 26 Safer 1230 (7 Şubat 1815). 
Haziran 1815'te Dergâh-1 Âli Kapıcıbaşılarından Hacı Osman her iki tabyaya bina emini, Sâbık Cebehâne Mühimmat Nâzırı Hüseyin Efendi de inşaat nâzırı olarak tayin edilir. ${ }^{34}$

Kısa bir süre sonra, tabyanın ilk teknik çizimlere göre bina edilmesi halinde, mühendisliğe

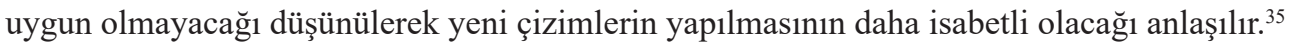
Bir yıl sonra Bina Emini El-hac Osman, inşaattaki rehavetinden dolayı azledilerek yerine Bahr-1 Sefid Boğazı gümrükçüsü Ahmed atanır. ${ }^{36}$ Bu arada inşaatın henüz devam ettiği 1816 tarihinde tabyada 21 top $^{37}$ bulunmakla birlikte, bunların çoğu yanan gemilerden çıkarılmış ve kullanılamaz durumdaki âhen toplardı. Hâlbuki Bigalı ve Nara tabyaları denize uzanan karşılıklı iki burun üzerine yapılmaktaydı ve bu nedenle her iki noktadan da istenilen yere atış yapabilme imkânı bulunuyordu. Dolayısıyla eski toplar yerine, Bigalı için farklı çaplarda toplam elli üç obüs ve yetmiş altı balyemez ${ }^{38}$ topuna ihtiyaç olduğu merkeze iletildi. ${ }^{39}$ Fakat Tuna sahilindeki kalelerin ihtiyacının aciliyetine binaen önceliğin bu kalelere verilmesi ve ardından da Bigalı ve Nara için gereken doksan altı büyük top ve altı adet humbara havanının dökülmesi uygun görüldü. ${ }^{40}$ Ocak $1817^{\prime}$ de Kala-1 Sultaniye Dizdarı ve Boğaz Muhafızı Hüseyin, Boğaz Gümrükçüsü ve Biga Sancağı Mütesellimi ve Bina Emini Ahmed Ağa, Sadrazam Hazinebaşı Yamağı Mehmed Hasib Ağa, Hazine Katibi Ahmed Ağa, Mimar Halifesi es-Seyyid Salih Ağa, Feyzi Bey-zâde Mîr Feyzi Efendi ve İbrahim Şeref ve diğer memur ve mühendisler marifetiyle yeni keşif yapıldı. Bu keşfe göre Bigalı Tabyası'nda siper temelleri, mutfak, bina eminlerine mahsus daire, bir adet ocaklı kahve odası, suyolları, mazgallar, lağım gideri, tuvalet ve iskele yapımı planlanmış ve o zamana kadar yapılan çalışmalar için 73.397,5 kuruş 50 para harcandığ 1 kayıtlara geçmiştir. ${ }^{41}$

Mayıs 1818 'de artık inşaat bitmek üzeredir ve Tophâne'de imal olunan yirmi iki adet kundak dingili Eğribozlu Nikola Reis'in gemisiyle Çanakkale'ye gönderilir. ${ }^{42}$ İnşaata takviye amaçlı gereken yüz adet amele, Biga Sancağı ve Maydos Köyü’nden karşılanır. ${ }^{43}$ Nihayet 1818 sonunda ve 332.000 kuruş masrafla Bigalı Kalesi tamamlanmış ve daha

34 BOA, C. AS. 141/6259.

35 BOA, HAT. 595/29210, 29 Zilhicce 1230 (2 Aralık 1815).

36 BOA, C. AS. 227/9641, 3 Muharrem 1232 (23 Kasım 1816). Arşiv kataloğunda bulunan 1212 yılı yanıltıcıdır.

37 BOA, C. AS. 813/34560, 7 Muharrem 1232 (27 Kasim 1816).

38 Osmanlı ordusunda "Balyemez" olarak isimlendirilen topun kökeninin, Alman yapımı Faule Metze topuna dayandığı hakkında bkz. Mark L. Stein, Osmanlı Kaleleri Avrupa'da Hudut Boyları, çev. Gül Çağalı Güven (İstanbul: İş Bankası, 2007), 38; Ömer Gezer, Kale ve Nefer, 124.

39 BOA, C. AS. 745/31345 Lef 7, 19 Zilhicce 1230 (22 Kasim 1815).

40 BOA, C. AS. 745/31345, 20 Cemaziyelevvel 1231 (18 Nisan 1816). Her iki tabyaya gerekli olan bakır Tophane'de mevcut olmadığından, Darphane'den 50.000 vukiyye bakır takviye yapılmıştır. BOA, C.AS. 142/6294, 25 Safer 1234 (24 Aralık 1818).

41 BOA, C.AS. 561/23567, 15 Safer 1232 (4 Ocak 1817). Her iki tabyanın inşaatını yürüten Bina Emini Ahmed Ağa'nın 150.000 kuruşluk miri senede ilaveten 150.000 kuruş talebine karşılık 20.000 kuruş gönderilebilmiştir. BOA, C.AS. 185/8028, 1 Ramazan 1232 (15 Temmuz 1817).

42 BOA, C.AS. 15/646, 7 Şevval 1233 (10 Ağustos 1818).

43 BOA, C.AS. 167/7322, 12 Ramazan 1233 (16 Temmuz 1818). 
önce Tophâne'ye sipariş olunan altmış üç adet toptan yirmi üçü hava şartlarının da müsait olması üzerine tüccar gemisi kiralanarak nakledilmiştir. Kalan kırk topun da aynı yöntemle nakledilmesi planlanır, fakat bu topların tüccar gemilerine sığmayacakları gerekçesiyle Tersâne-i Âmire'ye ait bir kalyonla gönderilmesine karar verilmiştir. ${ }^{44}$ Topların naklinin hemen ardından Bigalı ve Nara kaleleri için 30 kantar barut ile Kasımpaşa Karhânesi'nde imal edilen zincir, mikras, palankata, ${ }^{45}$ yuvarlak ve diğer harp malzemeleri ile kalelerin harp donanımı tamamlanmaya çalışılmıştır. ${ }^{46}$ Kalede bulunan topçu neferâtının düzenli talimleri için Asâkir-i Mansûre 7.Topçu Alayı Kolağası Hamza Ağa binbaşılığa terfi ettirilerek kalede görevlendirilir. ${ }^{47}$ Asker ve topçu mevcudu açısından 1835'te Bigalı Kalesi'nde 30 topçu neferi bulunmaktadır ve bunların mahiye, tayinat ve elbiseleri için senelik 300 kuruş tahsis edilmiştir. $^{48}$

Kale, mimarî açıdan 70x130m boyutlarında olup, dört köşesinde dairesel ve çokgen kuleler, doğu ve batı istikametinde iki giriş bulunmaktadır. ${ }^{49}$ Ek 1'de yer alan teknik çizim, kalenin Biga Mütesellimi Ahmed Ağa marifetiyle yaptırıldığını teyit eder. Bu çizime göre, kalenin deniz tarafındaki duvar hattı boyunca top siperleri, iç tarafta top seğirdimi ve hattın iki ucunda dairesel formda iki adet kule ve bunların hemen arkasında birer adet koltuk cephanesi ve iki adet çokgen yapıda karakolhane bulunmaktadır. Kalenin orta alanında çeşme ve cami ile doğu giriş kapısı önünde büyük cephanelik yer alırken, kara tarafı duvar hattı boyunca tüfek mazgalları, iki uçta birer adet çokgen tabya, iç kesimde piyade seğirdiminin olduğu görülür. Yine kara tarafı duvarına yakın ve paralel olarak iki girişli dikdörtgen şekilde neferât kışlası, bunun orta kısmında zabitan odaları, mutfak ve tuvaletler ile kalenin batı giriş kapısı yakınında mühimmât ambarı yer almaktadır. ${ }^{50}$

Bigalı Kalesi, ilerleyen yıllarda farklı ölçeklerde tamiratlar geçirir. Bunlardan ilki kale hizmete girdikten on iki yıl sonra gerçekleşir. Hassa mimarı hulefâsından İsmail Kemali’nin 1831'de yaptığı keşif sonucunda, Bigalı Kalesi'nde topçu zabitanları ve neferâtına mahsus odaların, tuvalet, lağım boruları ile siper ve mazgalların tamire muhtaç olduğu anlaşılmış ve

44 BOA, C.AS. 300/12447, 26 Zilkade 1233 (27 Eylül 1818); BOA, C.AS. 1042/45749, 25 Şaban 1235 (7 Haziran 1820).

45 Palanquate, Osmanlı belgelerinde geçtiği şekliyle Palankata, iki demir güllenin demir bir çubuk vasıtasıyla ortadan birleştirilmesiyle oluşturulan ve daha çok gemi serenlerini vurmakta kullanılan harp malzemesi. Bilgi için bk. Guiseppe Marco Antonio Baretti, A Dictionary Spanish and English, and English and Spanish, (London: Wingrave, 1794).

46 BOA, C.AS. 477/19887, 17 Receb 1236 (20 Nisan 1821); BOA, C.AS. 202/8681, 23 Safer 1236 (30 Kasim 1820).

47 BOA, HAT. 316/18562, 29 Zilhicce 1243 (12 Temmuz 1828).

48 BOA, HAT. 1344-52550, 29 Zilhicce 1250 (28 Nisan 1835).

49 Yusuf Acıŏ̆lu, “Çanakkale'deki Osmanlı Dönemi Savunma Yapıları” (Doktora Tezi, Çanakkale Onsekiz Mart Üniversitesi, 2013), 74.

50 T.C. Cumhurbaşkanlığı Milli Saraylar İdaresi Başkanlığı Topkapı Sarayı Yazma ve Matbu Eserler Koleksiyonu Arşivi H.1871. 
bu işler için 14.147 kuruş 60 para gerektiği tespit edilmiştir. ${ }^{51}$ Keşifte tamir edilmesi gereken yerler arasında bir de cami bulunmaktadır. Tabya veya kalelerde mescid veya caminin mutlak surette bulunduğu dikkate alındığında, 1815 ve 1817 tarihli inşaat keşif defterlerinde bahsi geçmeyen ve tarihsiz bir belgeye göre Dilgüşâ Camii ${ }^{52}$ olarak adlandırılan bu cami, muhtemelen inşaatın tamamlanmasına yakın bir tarihte inşa edilmiştir. Nitekim Ek 1'de yer alan çizimde cami net bir şekilde görülmektedir ve sağ altta kalenin bitmek üzere olduğu bilgisi bulunmaktadır.

İlk tamiratın yapıldığı 1831 tarihinde kalede, zabitan dahil 42 topçu neferâtı ile farklı ölçülerde 5 şayka, 16 balyemez ve 10'u da obüs olmak üzere toplam 31 adet top bulunuyordu. Ayrıca bir kale veya benzeri müstahkem bir yapıda olması gereken barut, hartuç, mahtab, top iğnesi, burgu, plastorya, ${ }^{53}$ dingil, manivela, fener, fișek, yuvarlak ve zincir gibi mühimmâtın mevcut olduğu ve bu malzemelerin ihtiyaca binaen zaman zaman takviye edildiği görülmektedir. ${ }^{54}$

1836 tarihli tamirat keşfinde asker kışlası, mühimmât ambarı, cephane, iskele, çeşme, lağım ve içme suyu hattının 521,5 kuruş 126 para masrafla tamiri gündeme gelir. ${ }^{55} 1848$ 'de Bigalı ile Çamburnu, Değirmenburnu, Namazgah ve Anadolu tarafinda Nara ve Köseburnu tabyalarının açık ve muhafazaya muhtaç olan kısımlarına 5-6 yük masrafla 11 adet palanka inşa edilerek bu yapılar desteklenir. ${ }^{56}$

1863 tarihinde Tophâne-i Âmire Meclisi'nin, Çanakkale Boğazı'ndaki tahkimat hakkında yaptığı tespit oldukça dikkat çekicidir. Buna göre, Boğaz tahkimatı- Cevdet Paşa'nın da ifade ettiği ve yukarıda belirtildiği üzere- eski tip yelkenli gemilerin ateş gücü dikkate alınarak yapılmıştı ve hâlihazırda zırhlı gemilerin savaş kabiliyetleri oldukça artmıştı. Dolayısıyla İstanbul'un kilidi mesabesinde olan Çanakkale Boğazı istihkamlarının yeni tip filolara karşı mukavemet edebilecek tarzda ve yeni teknik bilgiler dahilinde takviye edilmesi gerekiyordu. Bu amaçla Aktabya, Seddülbahir, Kumkale, Kala-1 Sultaniye, Kilitbahir, Namazgah, Mecidiye, Nara, Değirmenburnu, Çamburnu, Köseburnu ve Bigalı istihkamlarından bazılarının genişletilmesi ve Eskihisar, Kepezburnu ve Havuzlar'da yenilerinin yapılması kararlaştırılır. Ferik Ali Paşa başkanlığında oluşturulan komisyonda İstihkam Alayları Mirlivası Mehmed Paşa, Mühendishâne-i Berri-i Hümâyûn Nazırı İsmail Paşa ve Mühendishâne hocalarından

51 BOA, Baş Muhasebe Bina Eminliği Defterleri (D. BŞM. BNE. d.) 16393, 21 Rebiülevvel 1247 (30 Ağustos 1831).

52 BOA, HAT. Nr.1533/40. Belgede tarih bulunmamasına rağmen özetlerde Aralık 1815'e tarihlendirilmesi yanıltıcı görünmektedir.

53 Plastorya/plastorpa/plaster: Güllenin ateşleme sırasında zarar görmemesi için hartuçla arasına yerleştirilen zarf. Bkz. Fatih Yeşil ve Ömer Gezer, “Osmanlı İmparatorluğu’nda “Sürat” Topçuluğu II (1773-1807): Taktik, Talim, Muharebe Performansı ve Nizâm-1 Cedid," Osmanlı Araştırmaları 53 (2019), 247, n 40.

54 BOA, D. BŞM. TPH. d. 18874.

55 BOA, D. BŞM. BNE. d. 16462.

56 BOA, İ. MSM. 67-1932, 29 Rebiülevvel 1264 (5 Mart 1848). 
Miralay Blum ve topçu muallimlerinden Nadir Bey ve Tersâne'den Kaymakam Hüseyin Bey görevlendirilir. ${ }^{57}$

1894 'te yapılan tamiratta sağ taraf asker koğuşu 6541 kuruş 30 paraya elden geçirilmiş, ${ }^{58}$ 1906'da ise Kilye Lodos ve Poyraz, Çamburnu, Goncasuyu gibi Boğaz'da bulunan diğer müstahkem mevkiler ile birlikte Bigalı Kalesi'nin de muhtelif yerleri tamir edilmiştir. ${ }^{59}$ $\mathrm{Bu}$ arada Kırım Savaşı sırasında askerî amaçla kullanılan telgraf, savaşın hemen ardından Osmanlı coğrafyasında hızla yayılmış ve Ocak 1859'da Kilitbahir'den Çanakkale'ye bir denizaltı kablosu çekilerek hat Boğaz'a ulaşmıştır. ${ }^{60}$ Kilitbahir'den ikinci hat Şubat 1859'da Bigalı Kalesi'ne çekilmiş, buradan Nara Burnu'na deniz altından geçilmiş ve Boğaz'dan geçen gemilerin bu bölgede demir atmamaları için tedbir alınmıştır. Böylece KilitbahirKala-1 Sultaniye'den hattından sonra Boğaz'in en dar yerinde bulunan iki tabya dönemin en etkili haberleşme sistemi ile donatılmıştır. ${ }^{61}$

\section{Sonuç}

Çanakkale Boğazı'nın güvenliği, devletin on beşinci yüzyıl ortalarından itibaren hassasiyetle üzerinde durduğu konulardan olmuştur. Önce Venedik ve ardından da Rus tehlikesi, Çanakkale Boğazı'nda büyük kalelerin yapımını zorunlu kılmış ve on sekizinci yüzyıl sonrasında yabancı askeri uzmanların tavsiye ve gözetiminde nispeten küçük, fakat birbirlerini çapraz ateşle destekleyen tabyalar yapılmıştır. Bunlardan biri olan Bigalı Tabyası, Osmanl1-Rus geriliminin Aralık 1806'da savaşa dönüşmesi ve İngiltere'nin Bâbıâli yönetimini baskı altına almak amacıyla Şubat 1807 'de yaptığı harekât ile ortaya çıkmıştır. Dönem belgelerinde kısa bir süre Güllük olarak adlandırılan bölgede temelleri atılan Bigalı Tabyası'nın, İngiliz fillosunun Çanakkale Boğazı'ndan geçip İstanbul önlerine gelmesiyle alelacele inşa edildiği bizzat Sultan III. Selim tarafından da ifade ve tespit edilmiştir. Feyzullah Efendi'nin azli üzerine atanan Aziz Efendi'nin ifadesi, tabyanın yapımına İngiliz filosunun Çanakkale Boğazı'ndan geçişi ile başlandığını teyit etmektedir. Dolayısıyla Boğaz'ın en dar ikinci noktasının Rumeli tarafında, 1807 öncesinde herhangi bir müstahkem bir yapının olmadığı anlaşılmış olmakla birlikte, asıl dikkate değer olan nokta, diğer kale ve tabyaların da genel bir zafiyet içinde olduklarının ortaya çıkmasıdır.

Tabyanın mimarının, Boğaz'da birçok istihkâma imza atmasından hareketle Saint-Denys olabileceği akla gelecek ilk ihtimaldir. Ancak bunu teyit edecek bilgiye, Fransız mühendis

57 BOA, İrâde Dahiliye (İ. DH.) 516-35138, 8 CA 1280 (21 Ekim 1863); Ali Karaca, "Savunma Sisteminin Ana Unsuru İstihkamlar Bakımından Çanakkale Boğazı Tahkimi (1655-1915),” Yedinci Askeri Tarih Semineri Bildirileri I (Ankara: Genelkurmay Askerî Tarih ve Stratejik Etüt Başkanlığı, 2000), 317.

58 BOA, İrâde Tophane (İ. TPH.) 3/2, 11 Muharrem 1312 (15 Temmuz 1894).

59 BOA, İ. TPH. 15/21, 6 Cemaziyelevvel 1324 (12 Haziran 1906).

60 Özkan Keskin, “Telgrafın Osmanlı İmparatorluğu’nda Yayılması: Çanakkale Telgraf Hattı Örneği” Osmanlı Tarihi Araştırma ve Uygulama Merkezi Dergisi 25 (2011): 73, 74.

61 BOA, Hariciye Nezâreti Mektubi Kalemi (HR. MKT.) 277/42, 19 Receb 1275 (22 Şubat 1859). 
tarafından kaleme alınan eserde rastlanmadığı gibi, ekipte yer alan Coutaillout ismindeki mühendisin Bigalı Tabyası'nın mimarı olduğu dönem belgesi ile açıklığa kavuşmaktadır. Bigalı Tabyası, ilk vücut bulduğu anda mimarının ifadesi ile yirmi sekiz topa sahip bir askeri yapıdır ve bu sayının ilerleyen yıllarda küçük değişiklikler gösterdiği görülmektedir. Topçu neferâtı sayısının ise 30-40 arasında olduğu söylenebilir. Tabya, 1815 yılında muhkem bir tabyaya dönüştürülmek için geniş çaplı bir inşaata sahne olmuş ve yine aynı tarihten itibaren yapı belgelerde kale olarak adlandırılmaya başlanmıştır. İlerleyen yıllarda kale çeşitli tamirat ve eklemelerle elden geçirilmiş ve Kırım Savaşı sonrasında telgraf gibi dönemin yeni iletişim aracıyla teçhiz edilmiştir. Bigalı Kalesi, Çanakkale Savaşları sırasında tüfek tamir atölyesi olarak önemli bir görevi yerine getirmiştir. Kale bugün Çanakkale Savaşları Gelibolu Tarihi Alan Başkanlığ 1 tarafından restore edilmektedir. 


\section{EK 1 - Bigalı Kalesi'nin teknik çizimi.}

Kaynak: T.C. Cumhurbaşkanlığı Milli Saraylar İdaresi Başkanlığı Topkapı Sarayı Yazma ve Matbu Eserler Koleksiyonu Arşivi H.1871.

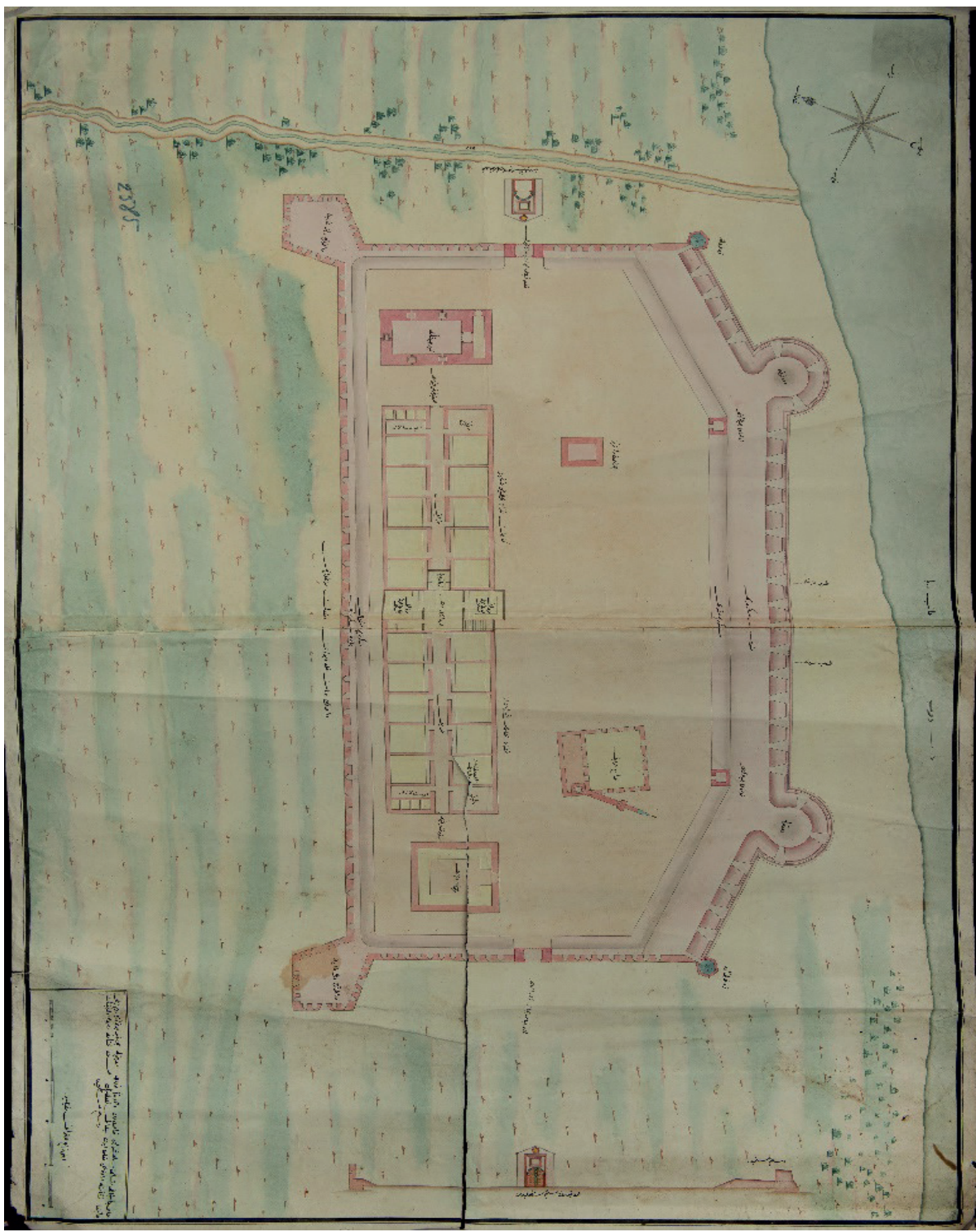


EK 2 - Bigalı Kalesi’nin War Office 331877 numarada kayıtlı planı.

Kaynak: Salih Murad Hatip, "Çanakkale Boğazı (Bahr-i Sefid Boğazı) Savunma Sistemi (17701918)" (Doktora Tezi, Hacettepe Üniversitesi, 2013), 102.

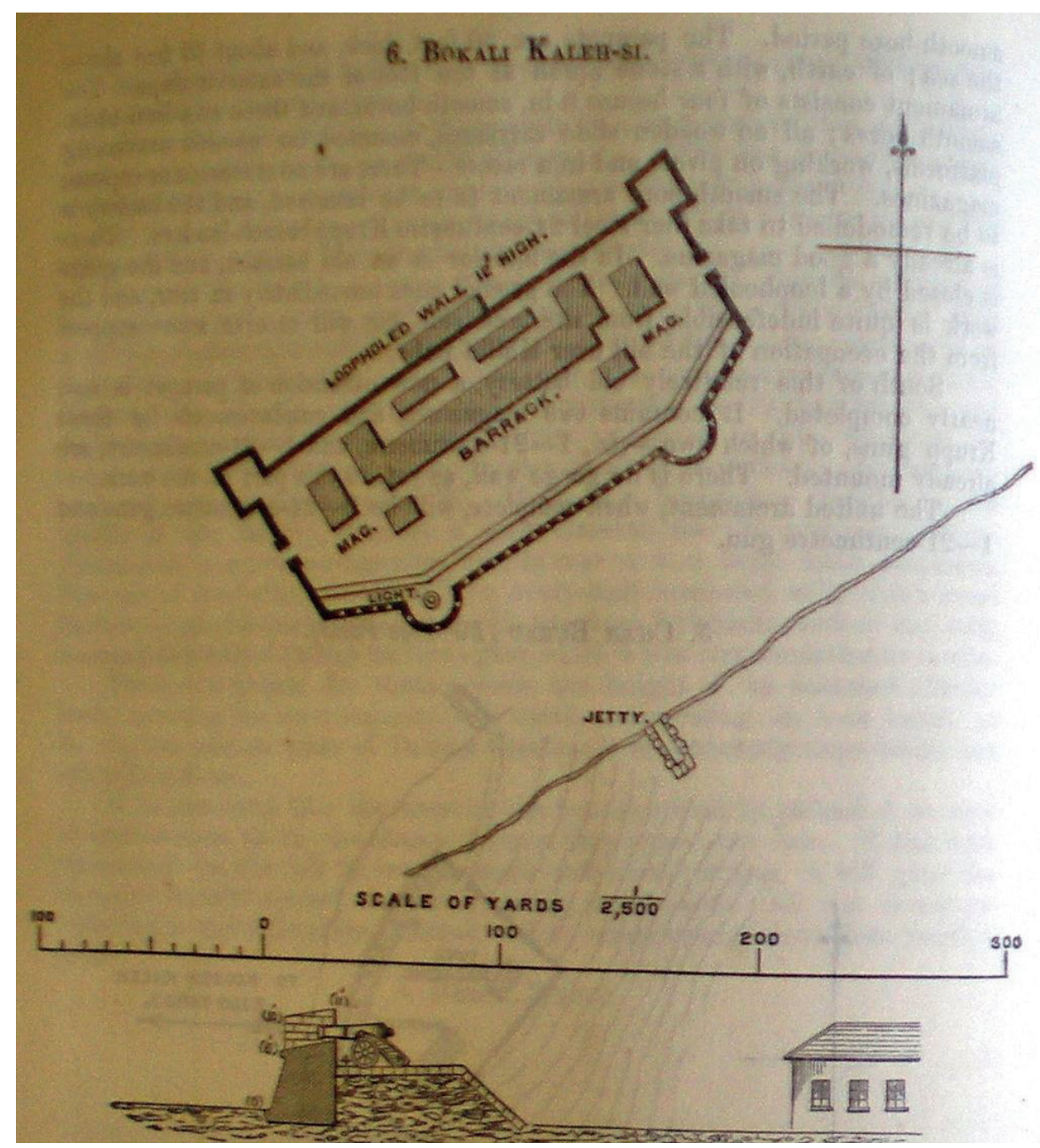




\section{EK 3 - Doğu Kapısı Restorasyon Öncesi}

Kaynak: Çanakkale Savaşları Gelibolu Tarihi Alan Başkanlığı Arşivi

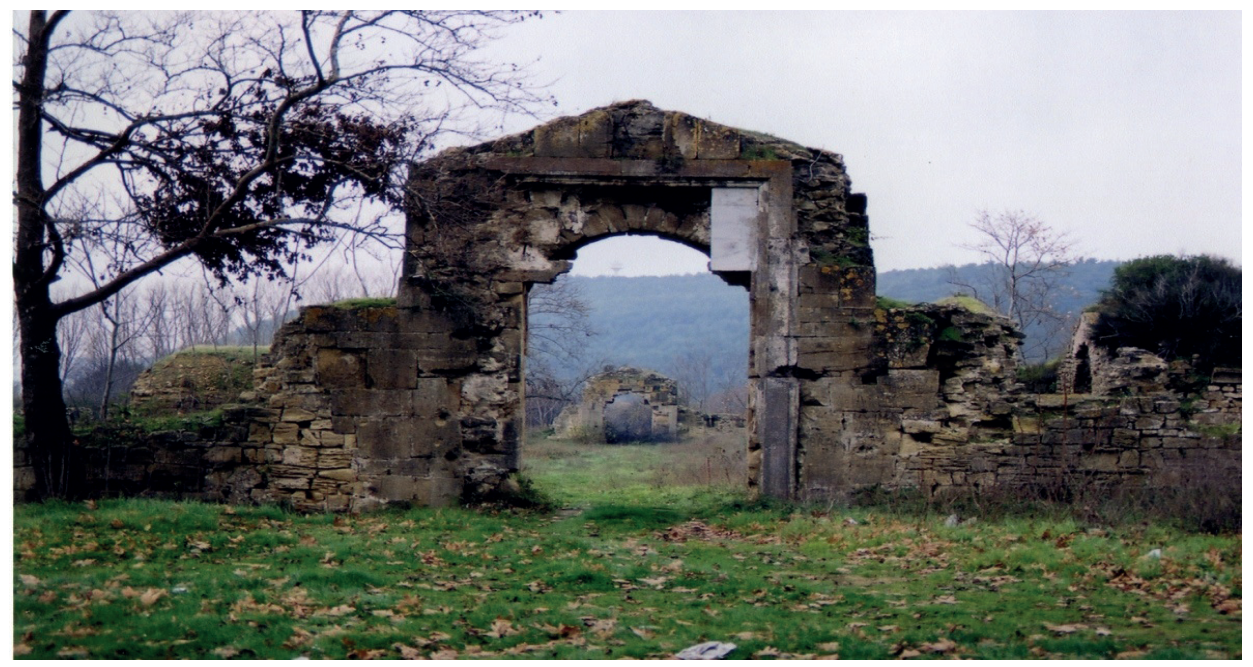

\section{EK 4 - Doğu Kapısı Restorasyon Sonrası}

Kaynak: Çanakkale Savaşları Gelibolu Tarihi Alan Başkanlığı Arşivi

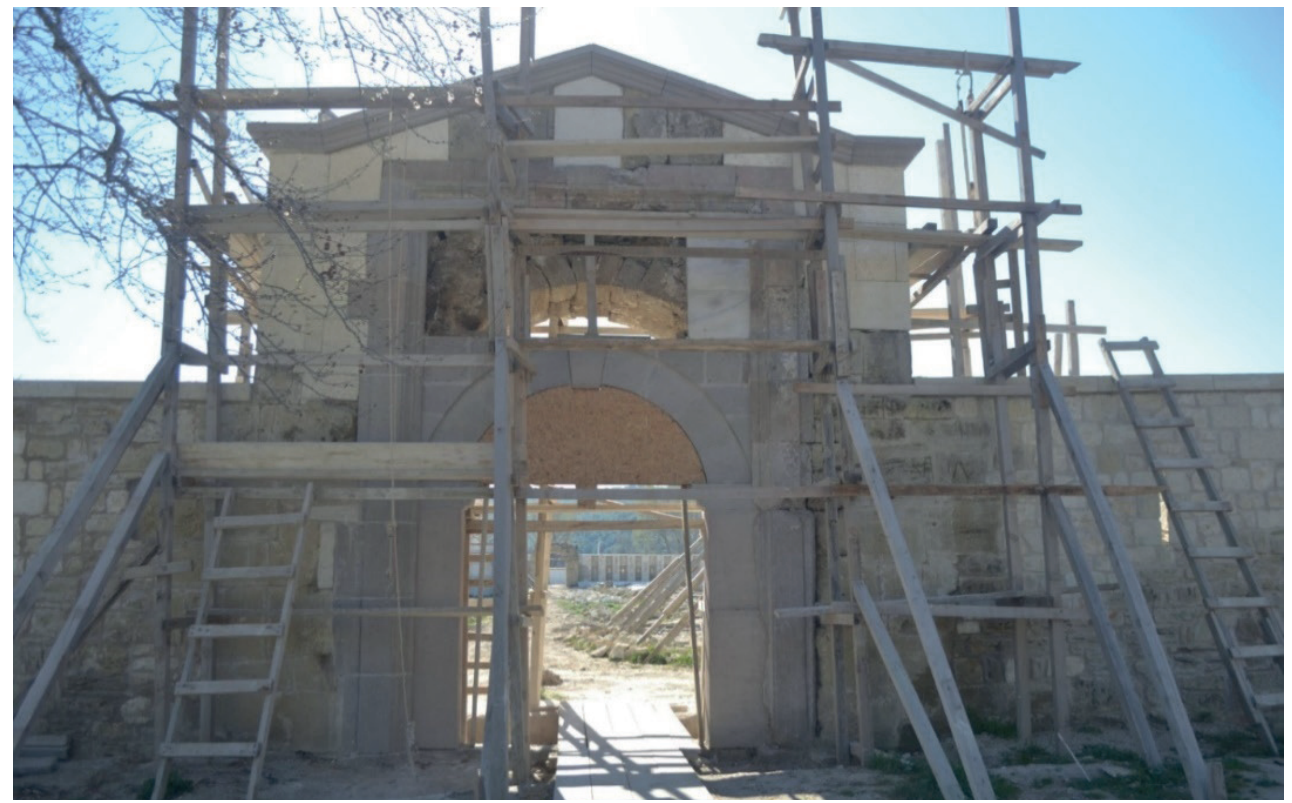




\section{EK 5 - Restorasyon Öncesi Durum}

Kaynak: Çanakkale Savaşları Gelibolu Tarihi Alan Başkanlığı Arşivi

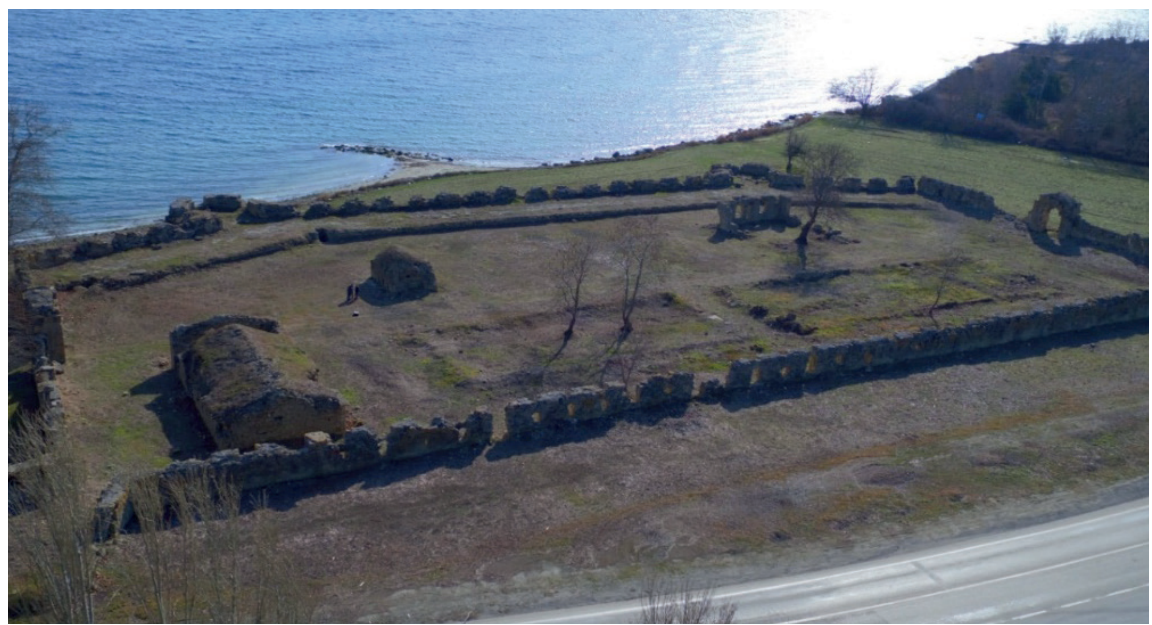

EK 6 - Eylül 2019 Restorasyon Çalışmaları

Kaynak: Çanakkale Savaşları Gelibolu Tarihi Alan Başkanlığı Arşivi

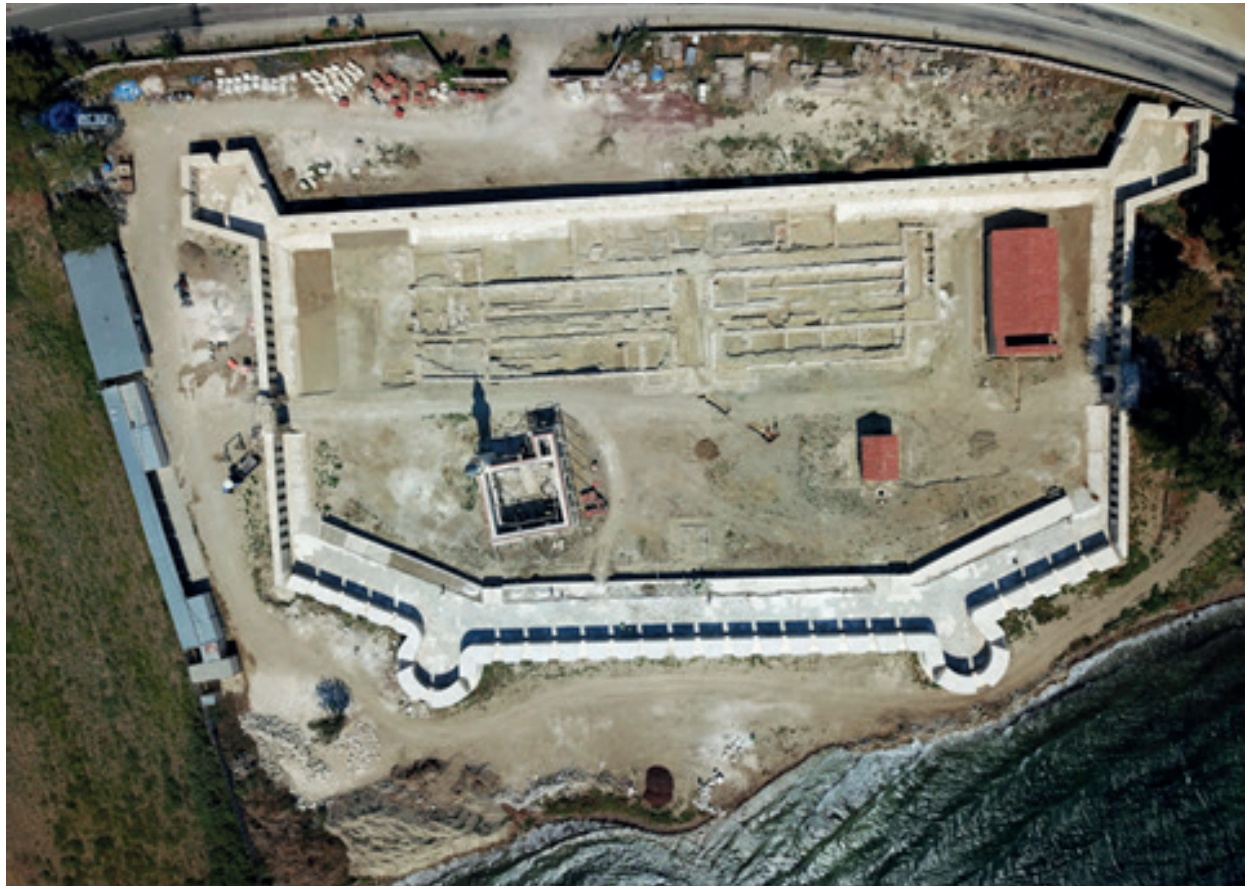




\section{EK 7 - Restorasyon Öncesi Durum}

Kaynak: Çanakkale Savaşları Gelibolu Tarihi Alan Başkanlığı Arşivi

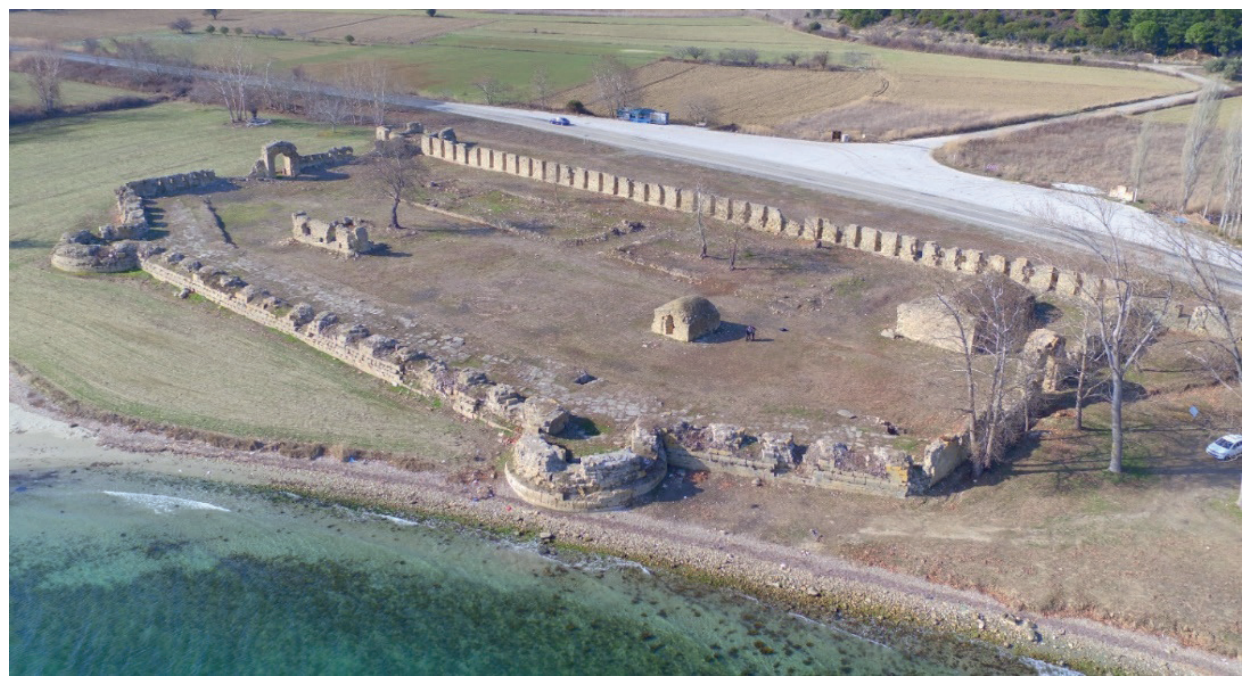

\section{EK 8 - Mayıs 2019 Restorasyon Çalışmaları}

Kaynak: Çanakkale Savaşları Gelibolu Tarihi Alan Başkanlığı Arşivi

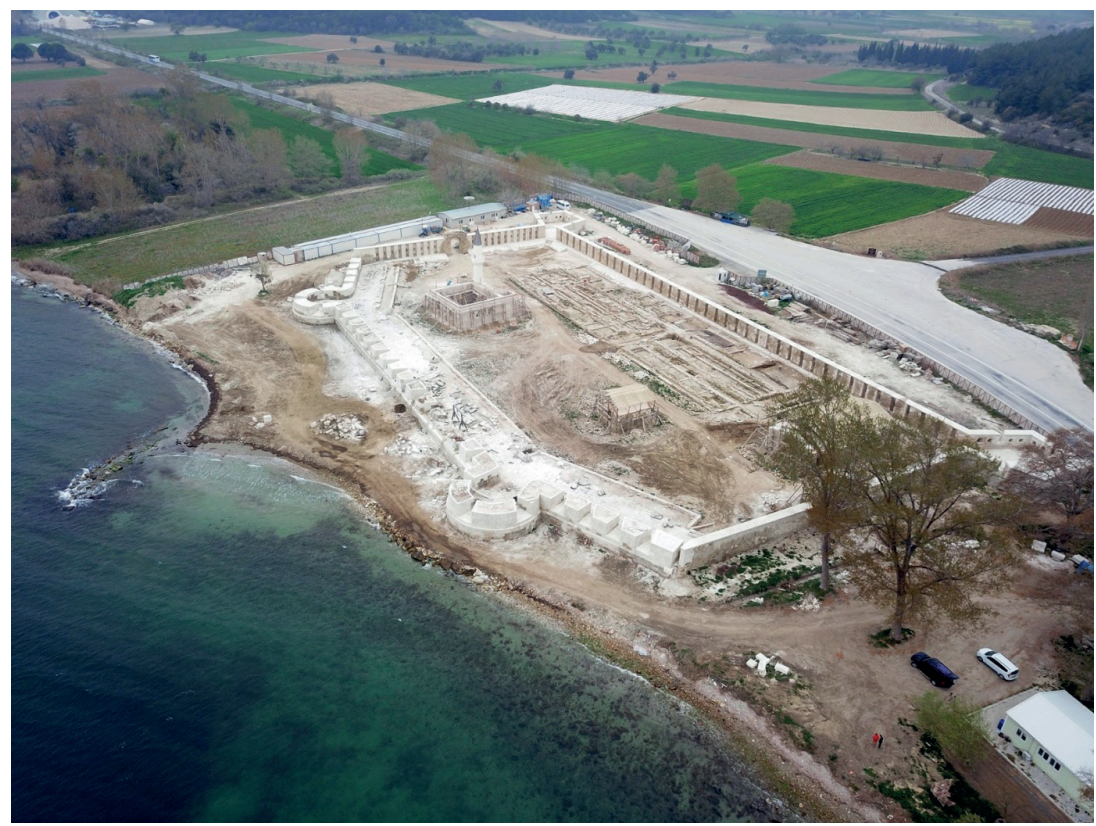




\section{EK 9 - Kalenin 1888-89 Yıllarındaki Durumu}

Kaynak: İstanbul Üniversitesi Nadir Eserler Kütüphanesi II. Abdülhamid Fotoğraf Arşivi

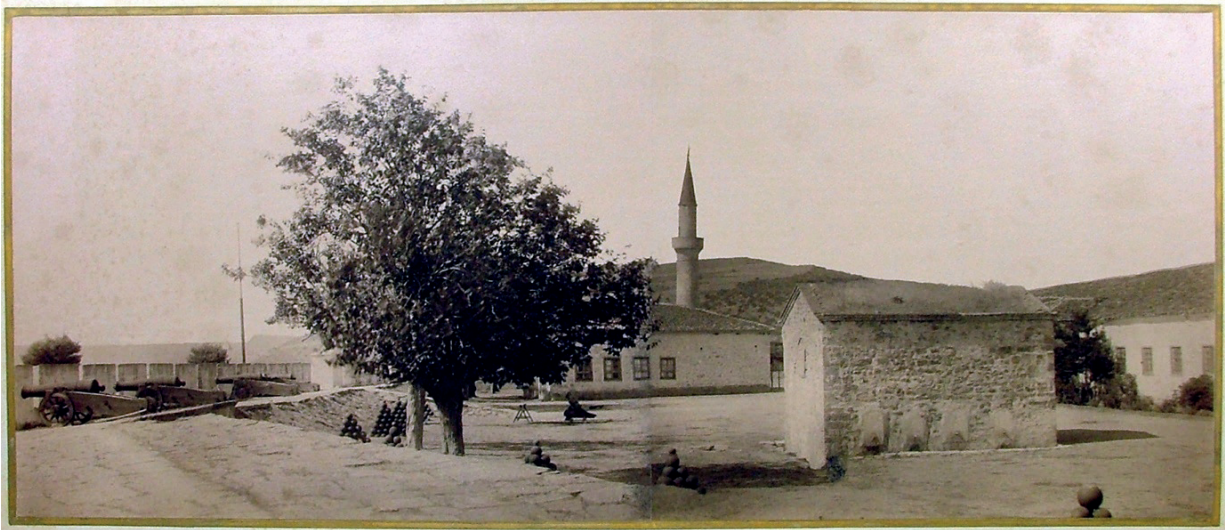

8.t.

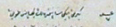

\section{EK 10 - Restorasyon Öncesi Durum}

Kaynak: Çanakkale Savaşları Gelibolu Tarihi Alan Başkanlığı Arşivi

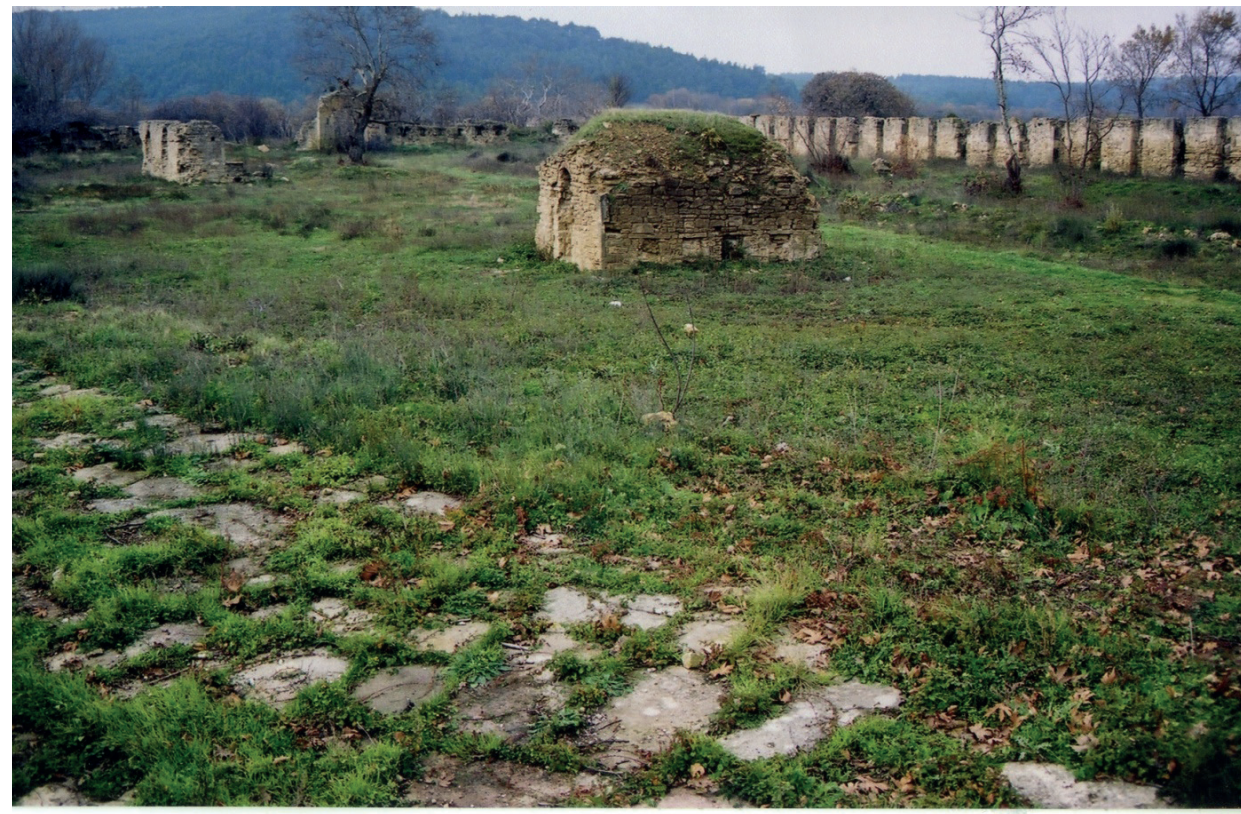


Hakem Değerlendirmesi: Dış bağımsız.

Çıkar Çatışması: Yazar çıkar çatışması bildirmemiştir.

Finansal Destek: Yazar bu çalışma için finansal destek almadığını beyan etmiştir.

Teşekkür: Bu çalışma, Çanakkale Savaşları Gelibolu Tarihi Alan Başkanlığı tarafından yürütülen "Bigalı Kalesi Restorasyon TeşhirTanzim" başlıklı proje kapsamında elde edilen verilerden de istifade edilerek hazırlanmıştır. Yazar, ekler bölümünde yer alan görsel malzemeyi kullanım izni veren Çanakkale Savaşları Gelibolu Tarihi Alan Başkanlığı'na ve ayrıca teknik terimlerde yardımlarını esirgemeyen Prof. Dr. Fatih Yeşil'e ve Doç. Dr. Cengiz Fedakâr'a teşekkür eder.

Peer-review: Externally peer-reviewed.

Conflict of Interest: The author has no conflict of interest to declare.

Grant Support: The author declared that this study has received no financial support.

Acknowledgements: The present article is based on data collected for the project "The Restauration of the Bigalı Port: Exhibition and Layout" carried out by the 'Directorate of the Gallipoli Historical Field - Dardanelles Wars'. The author thanks the directorate for allowing him to use the visual material displayed in the appendix of his article. He is also grateful to professor Dr. Fatih Yeşil and associate professor Dr. Cengiz Fedakâr for their assistance in designating the technical terms.

\section{KAYNAKÇA / BIBLIOGRAPHY}

\section{Arşiv Kaynakları / Archival Sources}

Çanakkale Savaşları Gelibolu Tarihi Alan Başkanlı̆̆ı Arşivi

İstanbul Üniversitesi Nadir Eserler Kütüphanesi II. Abdülhamid Fotoğraf Arşivi

T.C. Cumhurbaşkanlı̆̆ Devlet Arşivleri Başkanliğı Osmanlı Arşivi

Cevdet Askeriye (C. AS.) 15/646, 141/6259, 142/6294, 167/7322, 185/8028, 202/8681, 227/9641, 300/12447, 477/19887, 561/23567, 745/31345, 783/33154, 813/34560, 1042/45749

Cevdet Hariciye (C. HR.) 124/6183

Divan-1 Hümâyûn Baş Muhasebe Bina Eminliği Defterleri (D. BŞM. BNE.d.) 16393, 16462

Divan-1 Hümayûn Baş Muhasebe Tophane Defterleri (D. BŞM. TPH. d.) 18874

Hatt-1 Humâyûn (HAT.) 36/1847, 40/2007, 40/2016, 107/4206, 159/6636, 175/7598, 175/7598/H, 175/7614, 268/15663, 316/18562, 595/29210, 1344/52550, 1533/40

Hariciye Nezareti Mektubi Kalemi (HR. MKT.) 277/42

İrâde Dahiliye (İ. DH.) 516-35138

İrâde Mesâil-i Mühimme (İ. MSM.) 67-1932

İâde Tophane (İ. TPH.) 3/2, 15/21

T.C. Cumhurbaşkanlı̆̆ı Milli Saraylar İdaresi Başkanlığı Topkapı Sarayı Yazma ve Matbu Eserler Koleksiyonu Arşivi H.1871

Topkapı Sarayı Müzesi Arşivi Evrakı (TSMA.) 654-21

\section{Basılı Kaynaklar / Printed Sources}

Acıoğlu, Yusuf. "Çanakkale'deki Osmanlı Dönemi Savunma Yapıları.” Doktora Tezi, Çanakkale Onsekiz Mart Üniversitesi, 2013.

Ahmed Cevdet. Tarih-i Cevdet. 12 Cilt. Dersaadet: 1309.

Aydın, Mahir. "Kaleler,” Osmanlı Askeri Tarihi. Editör Gültekin Yıldız, 15-45. İstanbul: Timaş, 2017. 
Baretti, Guiseppe Marco Antonio. A Dictionary Spanish and English, and English and Spanish. London: Wingrave, 1794.

Cabi Ömer Efendi. Cabi Tarihi I. Hazırlayan Mehmet Ali Beyhan. Ankara: Türk Tarih Kurumu, 2003.

Driault, Édouard. Napoléon'un Şark Siyaseti Selîm-i Sâlis, Napoléon, Sébastiani ve Gardane. Mütercim: Köprülüzâde Mehmed Fuad, Çeviriyazı: Selma Günaydın. Ankara: Türk Tarih Kurumu, 2013.

Emecen, Feridun M. Osmanlı Imparatorluğu'nun Kuruluş ve Yükseliş Tarihi (1300-1600). İstanbul: İş Bankas1, 2015.

Eyice, Semavi. "Kale" Diyanet Vakfi İslam Ansiklopedisi. 24: 234-242. İstanbul: Diyanet Vakf1, 2001.

Fedakâr, Cengiz. Kafkasya'da Imparatorluklar Savaşı Kırım'a Giden Yolda Anapa Kalesi (1781-1801). İstanbul: İş Bankası, 2014.

Gezer, Ömer. Kale ve Nefer Habsburg Serhaddinde Osmanlı Askeri Gücü (1699-1715). İstanbul: Kitap Yayınevi, 2020.

Hatip, Salih Murad. "Çanakkale Boğazı (Bahr-i Sefid Boğazı) Savunma Sistemi (1770-1918).” Doktora Tezi, Hacettepe Üniversitesi, 2013.

İnalcık, Halil. Devlet-i 'Aliyye. 4 cilt. İstanbul: İş Bankası, 2012.

Karaca, Ali. "Savunma Sisteminin Ana Unsuru İstihkamlar Bakımından Çanakkale Boğazı Tahkimi (16551915)." Yedinci Askeri Tarih Semineri Bildirileri, I: 307-334. Ankara: Genelkurmay Askerî Tarih ve Stratejik Etüt Başkanlığı, 2000.

Keskin, Özkan. “Telgrafın Osmanlı İmparatorluğu'nda Yayılması: Çanakkale Telgraf Hattı Örneği.” Osmanlı Tarihi Araştırma Merkezi Dergisi 25 (2011): 67-81.

Mütercim Âsım Efendi. Âsım Efendi Tarihi. Hazırlayan Ziya Yılmazer, 2 cilt. İstanbul: Türkiye Yazma Eserler Kurumu Başkanlığı, 2015.

Puryear, Vernon J. Napoleon and the Dardanelles. Berkeley and Los Angeles: University of California Press, 1951.

Saint-Denys, Juchereau de, Révolutions de Constantinople en 1807 et 1808. Tome Second. Paris: Libraire de Brissot-Thivars, 1819.

Stein, Mark L. Osmanlı Kaleleri Avrupa 'da Hudut Boyları. Çeviren Gül Çağalı Güven. İstanbul: İş Bankası, 2007.

Şenocak, Lucienne Thys. Osmanlı Imparatorluğu'nda Kadın Baniler Hadice Turhan Sultan. Çeviren Ayla Ortaç. İstanbul: Kitap, 2009.

Tott, Baron de. Türkler ve Tatarlara Dair Hatıralar. İstanbul: Tercüman 1001 Temel Eser, ty.

Uzunçarşı11, İsmail Hakkı. Osmanlı Tarihi. Ankara: Türk Tarih Kurumu, 1995.

Yeşil, Fatih. "İstanbul Önlerinde Bir İngiliz Filosu: Uluslararası Bir Krizin Siyasi ve Askeri Anatomisi." Nizâm-ı Kadîm 'den Nizâm-ı Cedîd'e III. Selim ve Dönemi. Editör Seyfi Kenan içinde 391-493. İstanbul: İSAM, 2010.

Yeşil, Fatih. Trajik Zafer Büyük Güçlerin Doğu Akdeniz'deki Siyasi ve Askeri Mücadelesi (1806-1807). İstanbul: İş Bankası 2017.

Yeşil, Fatih ve Ömer Gezr. "Osmanlı İmparatorluğu'nda “Sürat” Topçuluğu II (1773-1807): Taktik, Talim, Muharebe Performansı ve Nizâm-1 Cedid." Osmanlı Araştırmaları 53 (2019): 231-285.

Yıldız, Aysel. "Vaka-yı Selimiyye or the Selimiyye Incident: A Study of the May 1807 Rebellion." Doktora Tezi, Sabancı Üniversitesi, 2008.

Zinkeisen, Johann Wilhelm. Osmanlı İmparatorluğu Tarihi. Çeviren Nilüfer Epçeli, çeviri kontrol Kemal Beydilli, editör Erhan Afyoncu, 7 cilt. İstanbul: Yeditepe, 2011. 
